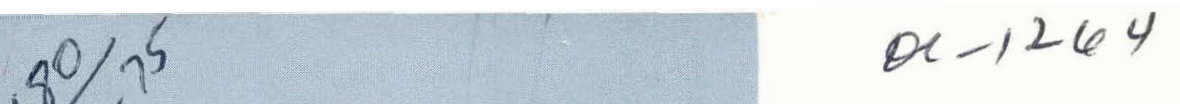

Y-1982

\title{
A DELAYED-FAILURE TEST METHOD FOR URANIUM AND URANIUM ALLOYS IN SELECTED ATMOSPHERES
}

V. C. Hemperly

\section{OAK RIDGE Y-12 PLANT} OAK RIDGE, TENNESSEE

\section{MASTER}




\section{DISCLAIMER}

This report was prepared as an account of work sponsored by an agency of the United States Government. Neither the United States Government nor any agency Thereof, nor any of their employees, makes any warranty, express or implied, or assumes any legal liability or responsibility for the accuracy, completeness, or usefulness of any information, apparatus, product, or process disclosed, or represents that its use would not infringe privately owned rights. Reference herein to any specific commercial product, process, or service by trade name, trademark, manufacturer, or otherwise does not necessarily constitute or imply its endorsement, recommendation, or favoring by the United States Government or any agency thereof. The views and opinions of authors expressed herein do not necessarily state or reflect those of the United States Government or any agency thereof. 


\section{DISCLAIMER}

Portions of this document may be illegible in electronic image products. Images are produced from the best available original document. 


\section{Printed in the United States of America. Available from}

National Technical Information Service

U.S. Department of Commerce

5285 Port Royal Road, Springfield, Virginia 22161

Price: Printed Copy \$4.00; Microfiche $\$ 2.25$

This report was prepared as an account of work sponsored by the United States Government. Neither the United States nor the Energy Research and Development Administration, nor any of their employees, nor any of their contractors, subcontractors, or their employees, makes any warranty, express or implied, or assumes any legal liability or responsibility for the accuracy, completeness or usefulness of any information, apparatus, product or process disclosed, or represents that its use would not infringe privately owned rights. 
Date of Issue: April 14, 1975

Report Number: Y-1982

Distribution Category: UC-38

\section{A DELAYED.FAILURE TEST METHOD FOR URANIUM AND URANIUM ALLOYS IN SELECTED ATMOSPHERES}

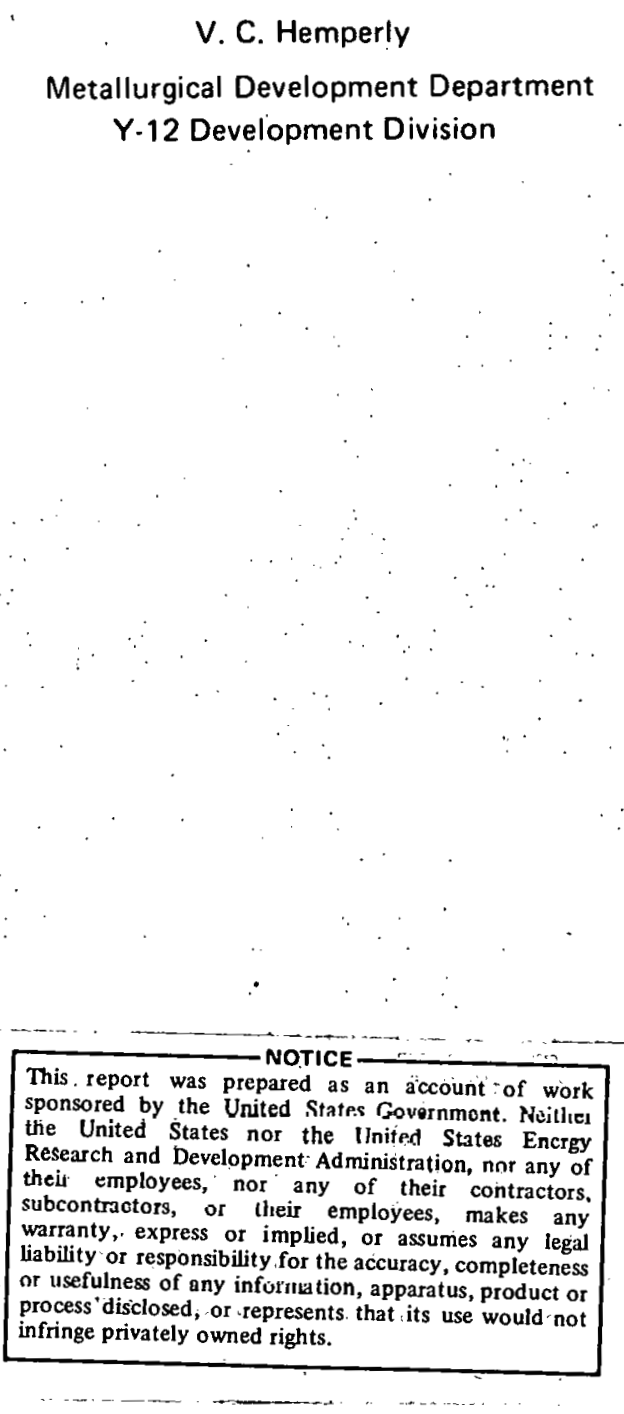

Oak Ridge Y-12 Plant

P. O. Box Y, Oak Ridge, Tennessee 37830

\footnotetext{
Prepared for the US Energy Research and Development Administration Under US Government Controct W 7405.eng. 26
} 


\begin{abstract}
Delayed-failure tests have been made on unalloyed uranium and on two uranium alloys. The delayed failures were obtained with static-load notched specimens in test atmospheres of laboratory air and dry argon, in vacuum, in distilled water, and in dilute nitric acid $(\mathrm{pH}, 4)$ at room temperature.
\end{abstract}




\section{CONTENTS}

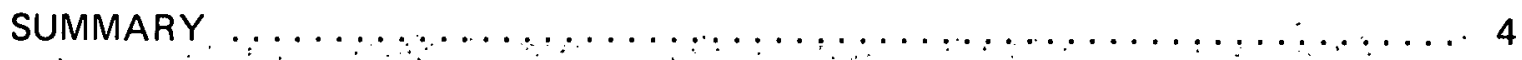

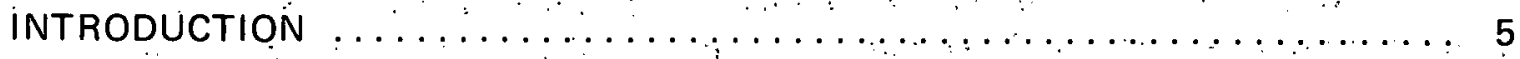

A DELAYED-FAILURE TEST METHOD $\ldots \ldots \ldots \ldots \ldots \ldots \ldots \ldots \ldots \ldots \ldots \ldots \ldots \ldots \ldots \ldots \ldots \ldots \ldots$

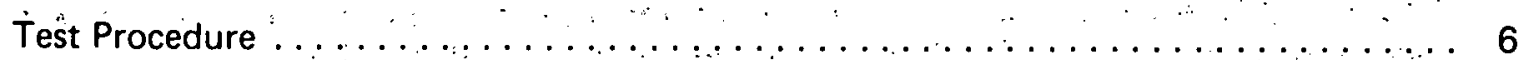

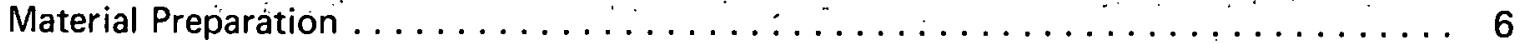

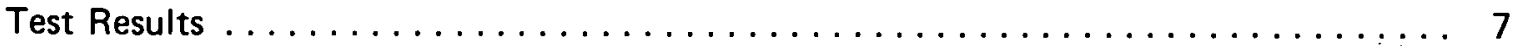

Test Evaluation $\ldots \ldots \ldots \ldots \ldots \ldots \ldots \ldots \ldots \ldots \ldots \ldots \ldots \ldots \ldots$

Relation to AWRE Results . . . . . . . . . . . . . . . . . . . . 9

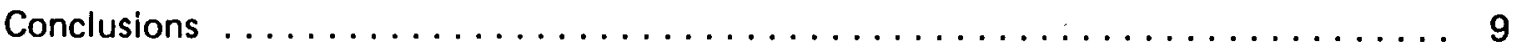

ACKNOWLEDGEMENTS $\ldots \ldots \ldots \ldots \ldots \ldots \ldots \ldots \ldots \ldots \ldots \ldots \ldots \ldots \ldots \ldots$ 


\section{SUMMARYY}

A test procedure was developed to obtain reproducible delayed failures at measurable stress levels. Curves showing stress level as a function of time to failure were prepared for unalloyed uranium, uranium-2 niobium-1 titanium (U-2 Nb-1 Ti) alloy, and uranium-8.5 niobium (U-8.5 Nb) alloy. Room-temperature static-load tests of notched specimens were made in laboratory air and dry argon, in vacuum, in distilled water, and in a dilute solution of nitric acid $(\mathrm{pH}, 4)$. These tests demonstrated differences due to test atmospheres as well as differences due to materials. Both the levels and the shape of the curves varied. 


\section{INTRODUCTION}

The purpose of this study, conducted at the Oak Ridge Y-12 Plant, (a) was to develop and evaluate a test procedure suitable for measuring the effects of different media on delayed failures in uranium and uranium alloys. The phenomenon of lowered ductility values in tensile tests of uranium and uranium alloys under water or in high-humidity air was originally described by the Atomic Weapons Research Establishment (AWRE), Aldermaston, England; (b) and has since been confirmed in other laboratories. A method was needed whereby the influence of a particular medium would be effective over a longer period of time than the few minutes required in the tensile test. However, the test method developed must be related to tensile tests conducted under water or in high-humidity atmospheres in order to ascertain that both methods do, in fact, measure the same metal/atmosphere characteristic. Then the specific effect of a longer exposure time to this test atmosphere could be examined. Static-load tests of notched specimens as a measurement of delayed failure due to hydrogen embrittlement has been used for some time (see the review by Troiano(c). However, the interest was not in metal/atmosphere effects as in the present study. In general, test variability with notched, static-load specimens has been reasonably low. The method used here consists of studying notched specimens that have been static loaded in selected atmospheres to obtain a curve of time to failure as a function 'of the applied stress level.

(a) Operated by the Union Carbide Corporation's Nuclear Division for the US Energy Research and Development Administration.

(b) Hughes, A. N., et al; "Environmental Factors Affecting the Mechanical Properties of Uranium", Journal of Nuclear Materials, 33 (1969).

(c) Troiano, A. R.; "The Role of Hydrogen and Other Interstitials in the Mechanical Behavior of Metals"', Transactions American Society for Metals, 53, p 55 (1960). 


\section{A DELAYED.FAILURE TEST METHOD}

\section{TEST PROCEDURE}

Test specimens were machined from the different materials to the dimensions indicated in Figure 1. It was necessary to grind the notches, because machined notches gave erratic results. Occasionally, because of a high stress concentration in that area, samples would break at the shoulder of the specimen rather than in the notch at the center. Any increase in the root diameter of the notch would necessitate a redesign of the specimen shoulder. The reported short-term breaking loads are average values obtained with a standard tensile testing machine in laboratory air. They were used only to estimate the stress level for the first static-load test, and have no other significance in the test method.

All of the static-load tests reported in this study were obtained with specimens having the oxide coating that normally develops on machined surfaces. Early in the experiment, the oxide had been removed from two specimens with phosphoric acid, immediately prior to loading. These two specimens were not appreciably different from those with the oxide not removed. The oxide layer probably does affect the metal/atmosphere reaction, but its influence was not sufficient to be measured in this test method.

The specimens were dead loaded to the desired stress level in standard creep machines. Distilled water, dilute nitric acid $(\mathrm{pH}, 4)$, or dry argon were contained around the notched area of the specimens with rubber tubing. Both of the liquid atmospheres were static, while the argon gas was passed through the tubing for the duration of the test. The tests in vacuum were performed in a fixture designed for that purpose.

\section{MATERIAL PREPARATION}

The unalloyed uranium specimens having a nominal hydrogen level were taken from a plate that had been prepared by vacuum-induction casting, alpha rolling, and alpha annealing in a salt bath. The hydrogen in the metal was $1.57 \mathrm{ppm}$. The unalloyed uranium specimens

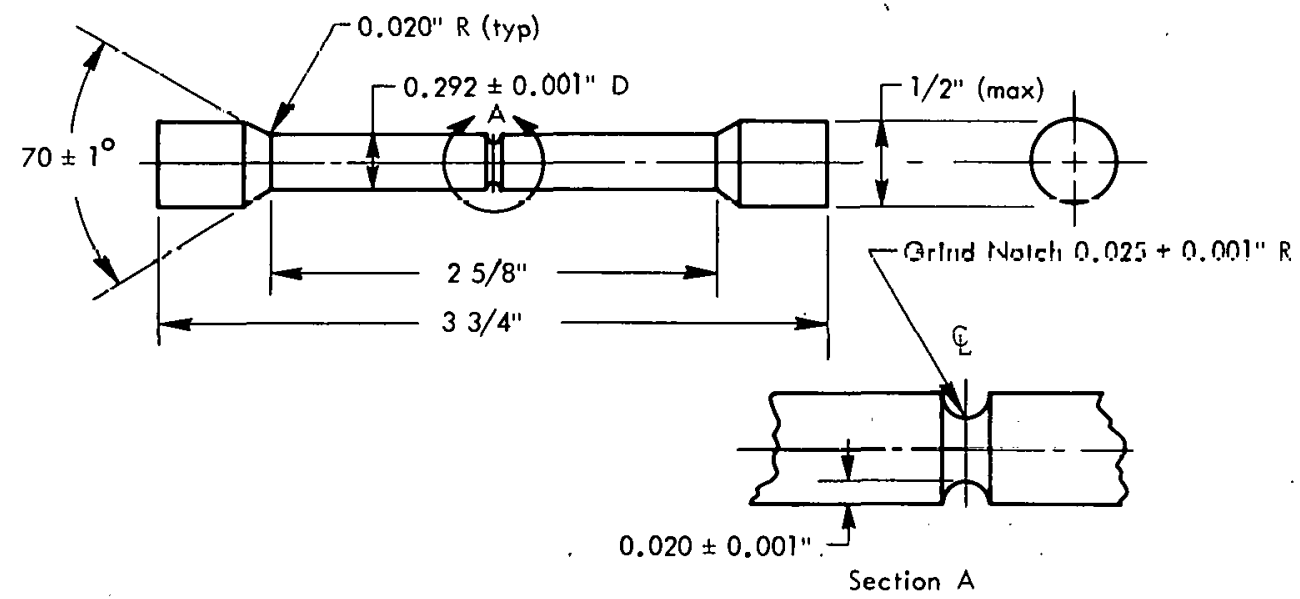

Figure 1. NOTCHED SPECIMEN FOR DELAYED-FAILURE TESTING. 
having a low hydrogen level were taken from a plate that had been prepared by vacuum-induction casting, alpha rolling, alpha annealing in a salt bath, and then vacuum outgassing at $700^{\circ} \mathrm{C}$ for 24 hours. The hydrogen after this treatment was $0.14 \mathrm{ppm}$.

The U-2 Nb-1 $\mathrm{Ti}$ alloy was prepared by comelting the elements in a vacuum-induction furnace, casting, and gamma rolling from a salt bath. The plate was vacuum-water quenched from $800^{\circ} \mathrm{C}$ and then vacuum aged at $200^{\circ} \mathrm{C}$ for 24 hours plus $300^{\circ} \mathrm{C}$ for 24 hours. The hydrogen was $12 \mathrm{ppm}$. The U-8.5 Nb alloy was prepared by double arc melting the elements, hot upsetting, and gamma rolling from a salt bath. The plate was vacuum-water quenched from $800^{\circ} \mathrm{C}$, and vacuum aged at $200^{\circ} \mathrm{C}$ for five hours. The hydrogen was 0.8 ppm.

\section{TEST RESULTS}

\section{Test Evaluation}

To evaluate the effectiveness of the test procedure, specimens of unalloyed uranium, U.8.5 $\mathrm{Nb}$, and $\mathrm{U}-2 \mathrm{Nb}-1 \mathrm{Ti}$ were static loaded in laboratory air, in vacuum, and in distilled water: Although there was some test variability, it was not of sufficient magnitude to negate the method. The tests did, in fact, measure the metal/atmosphere effects upon delayed failure.

Figure 2 is a graph showing the delayed-failure times versus stress levels for the unalloyed, beta-annealed uranium in laboratory air, in a vacuum, and in distilled water. Delayed failures in a vacuum were at higher stress levels and delayed failures in water, were at lower stress levels than those in laboratory air. The water curve has a very sharp knee compared with the other two.

Figure 3 presents similar delayed-failure curves for the U-8.5 Nb alloy in laboratory air and in a vacuum. The two curves developed are similar in shape, with the test results in laboratory air above those in a vacuurr.

Fracture surfaces from failed specimens of the U.8.5 Nb alloy (in both atmospheres) were examined with the scanning electron microscope (SEM). Both groups of specimens showed the same mixed intergranular and ductile dimple fracture modes. The similarity in

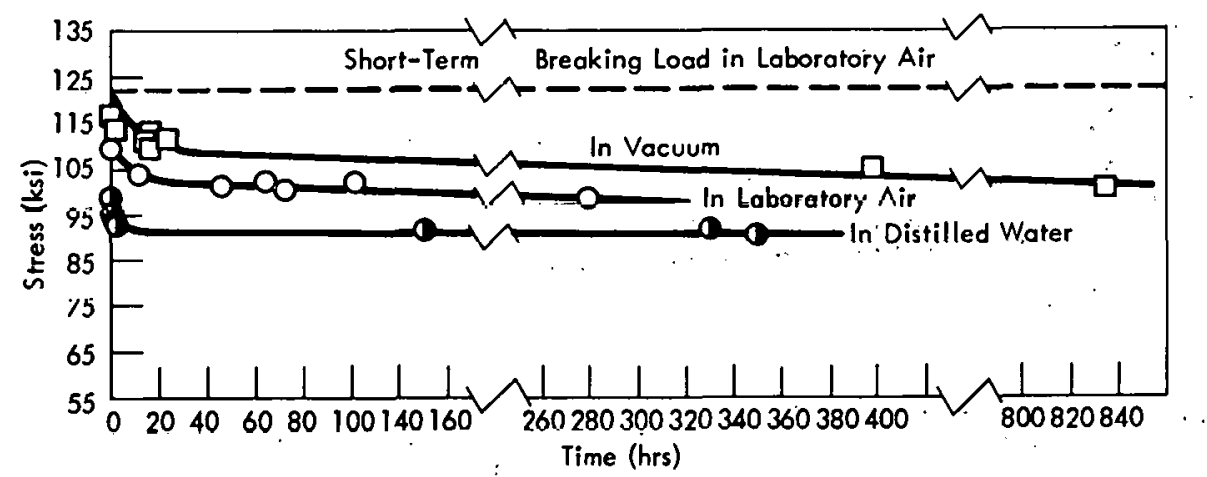

Figure 2. ROOM-TEMPERATURE STRESS:RUPTURE TESTS ON BETA-ANNEALED. UNALLOYED URANIUM. 


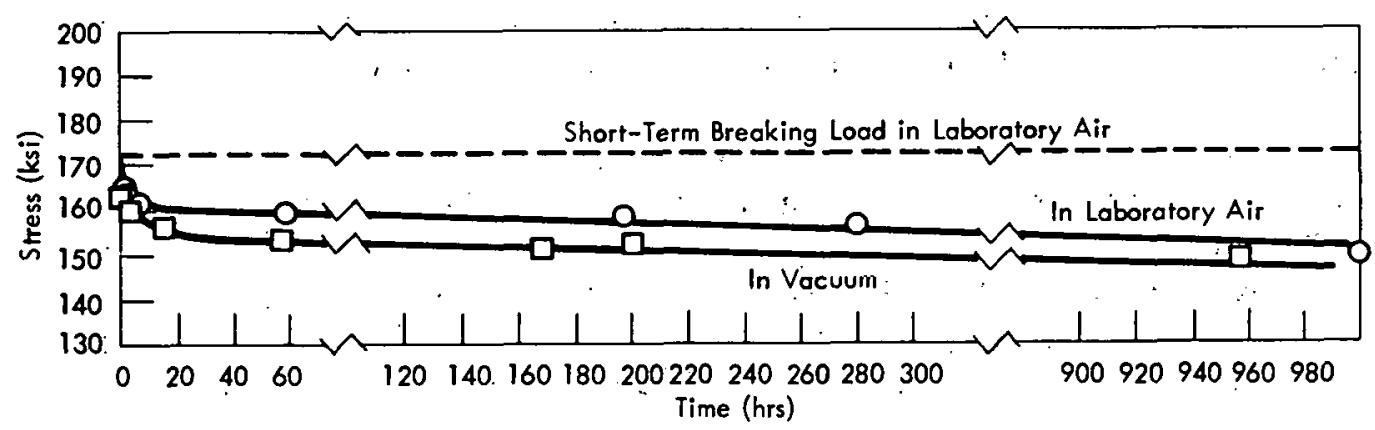

Figure 3. ROOM-TEMPERATURE STATIC.LOAD TESTS ON URANIUM-8.5 NIOBIUM ALLOY.

fractrography suggests that the fracture mechanism in operation is independent of the test atmosphere. However, this observation may not be true with all atmospheres.

Data from the U-2 Nb-1 Ti alloy in laboratory air and in dry argon are plotted in Figure 4. In the dry-argon atmosphere, the results were too variable to permit drawing a delayed-failure curve, but the variability here is probably a material variability rather than a testing-technique variability. In laboratory air, the results were consistent and showed a curve segment where delayed-failure times were relatively independent of the stress level, such as normally obtained with hydrogen-embrittled, high-strength steels.

Fractures from these delayed-failure tests showed a darkened, oxidized spot on one side. The spot was not always evident in specimens fractured in a minute or two, but was always seen in long-time fractures. In unalloyed uranium, the spot was evident in fractures from air testing; and, after vacuum tests, the spot developed shortly after removal from the chamber. The spot was slow in developing in the U-8.5 Nb alloy. Incidentally, similar spots also occur occasionally in tensile tests of unalloyed uranium, and such specimens always have low

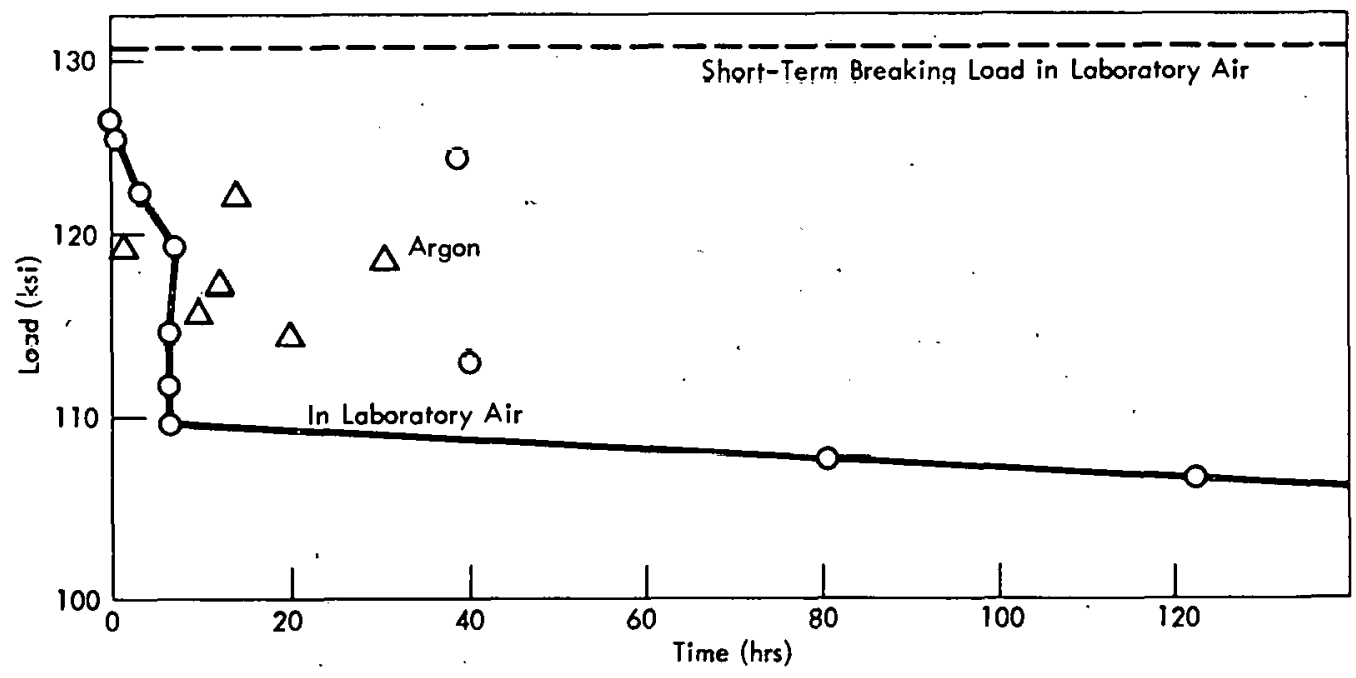

Figure 4. ROOM-TEMPERATURE STRESS-RUPTURE TESTS ON URANIUM-2 NIOBIUM-1 TITANIUM ALLOY. 
reduction-in-area values. The observation suggests a difference in fracture surface energy; and; therefore, a difference in the fracture mechanism. The resolution of this point will require further experimentation.

The static load tests of notched specimens showed little test variability, and delayed failures could be related to the test atmosphere. Therefore; two sets of samples were tested to establish that the delayed-failure test developed here did measure the same metal/atmosphere characteristic as did the AWRE tests, but with a longer time exposed to the test atmosphere.

\section{Relation to AWRE Results}

In one set, the delayed-failure curves were developed in laboratory air, water at a pH of 4, and distilled water. AWRE had shown lowered ductility in distilled water, with lesser effects at $\mathrm{pH}$ levels both above and below 7 . The material was unalloyed uranium in the as-rolled condition. In Figure 5, the curve for laboratory air is closer to the short-term breaking load than in any of the other tests, probably because of the very low strength of this material. The three curves are in the same order as the AWRE tensile tests in similar atmospheres. This fact indicated that the delayed-failure test was measuring the same metal/atmosphere characteristics as the AWRE tests.

In the other set, beta-annealed, unalloyed uranium was prepared at two levels of hydrogen content to obtain tensile-test ductility at two different levels. Tensile tests of both alloys were made in laboratory air and under water, with the results listed in Table 1. Ductility and tensile strength were both lower when tested under water than when tested in air. Figure 6 shows the delayed-failure curves for the two materials. The samples with the higher ductility in tensile tests under water provided a curve well above the lower-ductility material. These results, however, did not help demonstrate that the AWRE tests and the delayed-failure tests were measuring the same metal/atmosphere characteristic. Their tensile strengths were dissimilar when similar tensile strengths had been anticipated.

\section{CONCLUSIONS}

Static-load tests of notched specimens did produce delayed failures in uranium and uranium alloys with very little test variability. The shape and level of the delayed-failure curves of

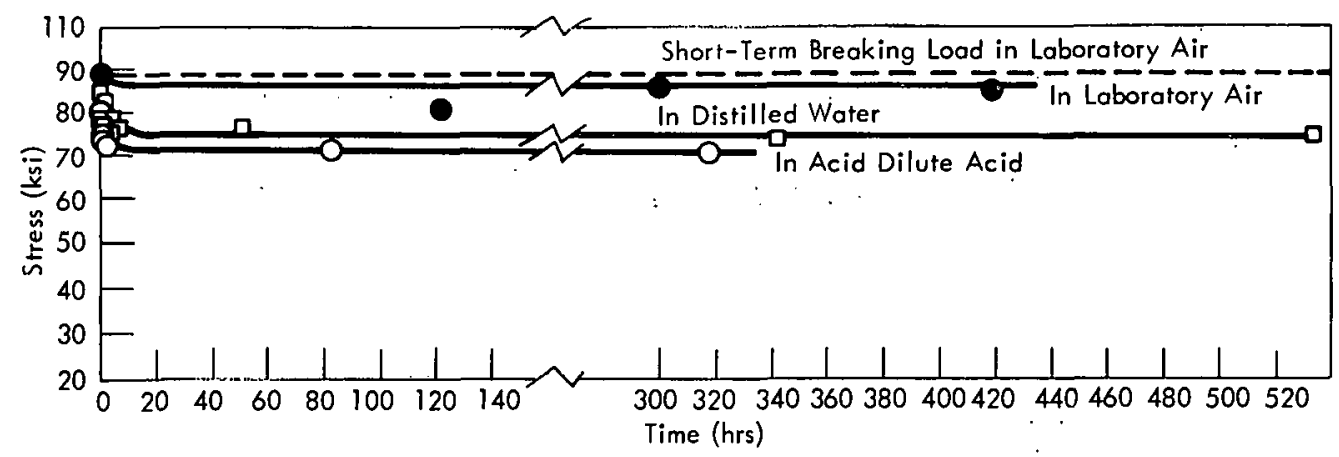

Figure 5. ROOM-TEMPERATIIRE STATIC.LOND TESTS ON UNALLOYED URANIUM. 
Tajle 1

TENSILE TESTS OF LOW AND H GH-HYDROSEN URANIUM IN LA.BORATORY AIR AND UNDER NATER

\begin{tabular}{|c|c|c|c|c|c|}
\hline \multirow{2}{*}{$\begin{array}{c}\text { Hydrogen } \\
\text { Content } \\
\text { (ppm) }\end{array}$} & & \multicolumn{2}{|c|}{$\begin{array}{l}\text { Tensile } \\
\text { Strergth }\end{array}$} & \multirow{2}{*}{$\begin{array}{c}\text { Elongation }\left({ }^{-}\right) \\
\{\%:\end{array}$} & \multirow{2}{*}{$\begin{array}{c}\text { Reduction } \\
\text { in } \\
\text { Area } \\
(\%) \\
\end{array}$} \\
\hline & & (ksi) & (MPa) & & \\
\hline \multicolumn{6}{|c|}{ In Lab=ratcory Air } \\
\hline \multirow[t]{4}{*}{0.23} & & 85.7 & $59 \mathrm{C}$ & 6.0 & 10.0 \\
\hline & & 94.3 & 650 & 12.0 & 17.4 \\
\hline & & 86.8 & 59ع. & D & 10.8 \\
\hline & Average & 88.9 & 61\%: & $\varepsilon .7$ & 12.7 \\
\hline \multirow[t]{3}{*}{0.82} & & 72.8 & $50 \Xi$ & 5.0 & 6.3 \\
\hline & & 73.0 & $50 \Xi$ & 5.5 & 5.5 \\
\hline & & 72.7 & 501 & 5.0 & 7.2 \\
\hline , & Average & 72.8 & 502 & 5.2 & 6.3 \\
\hline \multicolumn{6}{|c|}{ In Distilled Water } \\
\hline \multirow[t]{4}{*}{0.23} & & 74.3 & 512 & $\angle .0$ & 5.3 \\
\hline & & 77.4 & 532 & 6.0 & 4.0 \\
\hline & & 73.0 & 503 & $6: 0$ & 6.8 \\
\hline & Average & 74.9 & 516 & 5.3 & 5.4 \\
\hline \multirow[t]{4}{*}{0.82} & & 65.7 & 453 & 3.5 & 3.5 \\
\hline & & 65.8 & 453 & 35 & 3.2 \\
\hline & & 68.0 & 469 & 35 & 3.6 \\
\hline & Average & 66.2 & 456 & 35 & 3.4 \\
\hline
\end{tabular}

(1) In one inch.

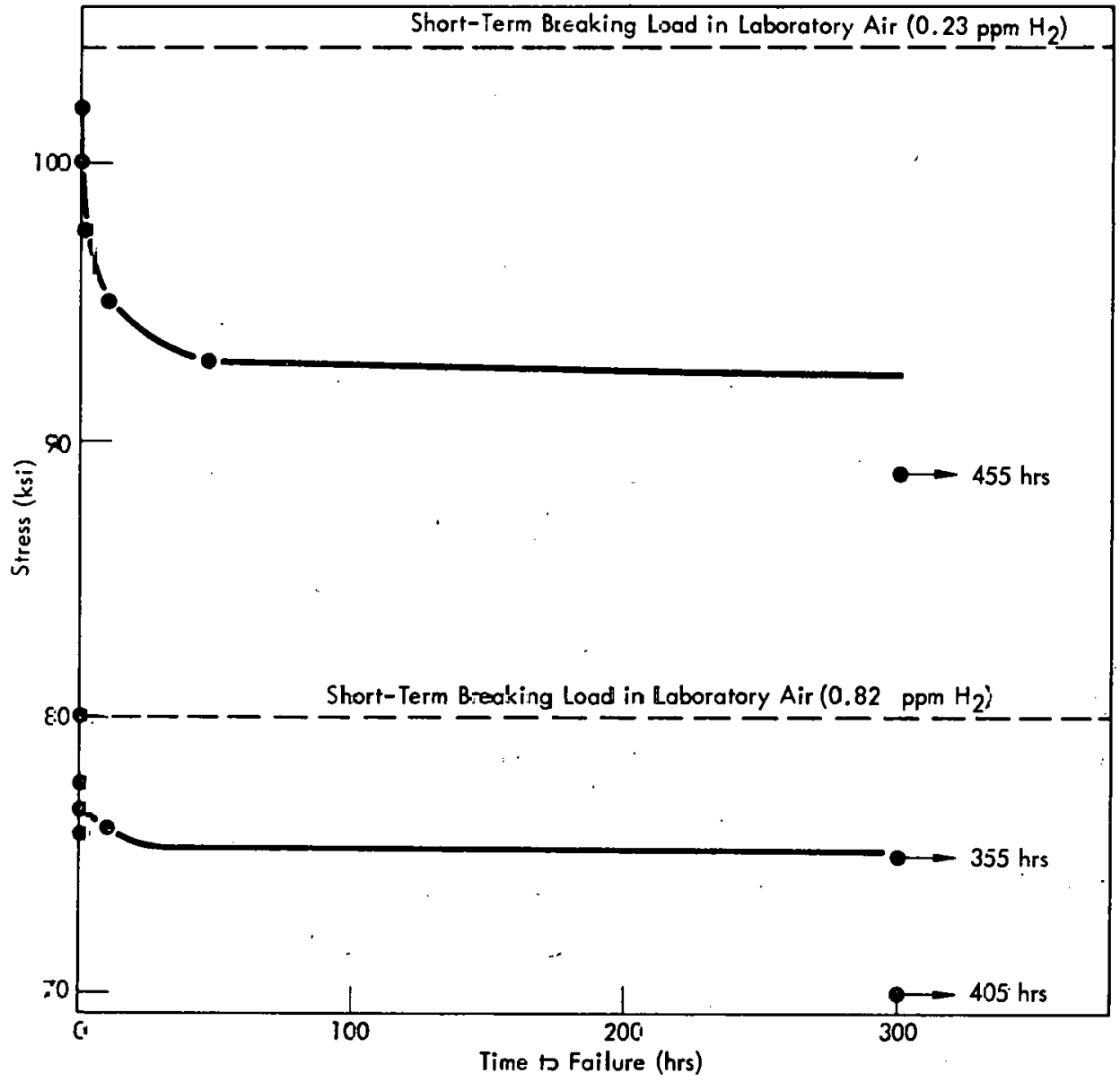

Fišre 6. DELAYEd faIluRES of STATIC-LOADED, NOTCHED SPECIMENS OF UNALLOYED URANIUM. 
time to fracture versus the stress level varied with both materials and with the test medium, so the technique provides a quantitative measure of the delayed failure of metal/atmosphere couples. The test method measures the same metal/atmosphere characteristic as does the AWRE tensile test technique.

A very limited fractographic study suggested that the fracture mechanism of delayed failure was independent of the test medium, at least with respect to laboratory air and in vacuum. Observations on the oxidized spot on the delayed-failure fractures suggests that there may be two fracture mechanisms operating. These two points will require additional experimentation for complete understanding.

The delayed-failure test results in this study are not readily explained as corrosion effects. Instead, it is suggested that the failures are truly by a hydrogen-embrittlement mechanism. The atmosphere effect is associated with how rapidly the hydrogen in the metal at the notch area is lost to the atmosphere. For example, oxygen in the air reacts with the hydrogen at the metal surface, thus reducing the amount of hydrogen available in the metal for hydrogen embrittlement of the specimen; and, therefore, delays failure. On the other hand, water as the test medium has little tendency to remove hydrogen and so permits delayed failure at an earlier time. Tensile tests in similar media are similarly affected, but on a dynamic basis. 


\section{ACKNOWLEDGEMENTS}

The author wishes to thank S. G. Campbell, Y-12 Plant, and L. K. Egner, Holifield National Laboratory, for performing the tests for this study. 


\section{Distribution}

Energy Research and Development Administration - Oak Ridge

Hickman, H. D.

Leed, R. E.

Zachry, D. S., Jr

Technical Information Center (2)

Oak Ridge Gaseous Diffusion Plant

Wilcox, W. J., Jr

Winkel, R. A.
Yaggi, W. J./Googin, J. M.

Y-12 Central Files (5)

Y.12 Central Files (master copy)

$Y-12$ Central Files (route copy)

$Y-12$ Central Files ( $Y-12 R C)$

Zerby, C. D.

\section{Paducah Gaseous Diffusion Plant}

Levin, R. W.

Oak Ridge Y-12 Plant

Alvey, H. E.

Bernander, N. K.

Burditt, R. B.

Burkhart, L. E.

Campbell, S. G.

Dodson, W. H.

Ebert, T. H.

Ellingson, R. D.

Fraser, R. J.

Gritzner, V. B.

Hemperly, V. C.

Jackson, V. C.

Jones. F. W.

Kahl, K. G.

Keith, A.

Kite, H. T.

Koger, J. W.

Ludwig, R. L.

Lundin, M. I.

Mills, J. M., Jr

Phillips, L. R.

Schreyer, J. M.

Smith, H. F., Jr

Smith, R. D.

Stoner, H. H.

Tewes, W. E.

Tilson, $F . V$.

Townseñd, A. B.

In addition, this report is distributed in accordance with the category UC-38, Engineering and Equipment, as given in the USERDA Standard Distribution Lists for Unclassified Scientific and Technical Reports, TID-4500. 